\title{
Learning Styles Activity level and Medical Students' Learning Performance
}

\author{
Deeba Qudsia \\ Department of Education, University of Karachi, Pakistan \\ Received: August 3, 2020 \\ Received in Revised: August 11, 2020 \\ Accepted: August 13, 2020
}

\begin{abstract}
The activity level relationship of learning styles and the level of activity relationships intracampus activities to the achievement of the medical students. The design used in this study is analytical category using cross sectional approach. Data were analyzed using Chi-Square test. The results of the analysis with chi-square test found a correlation between the activity level relationship of study style to academic achievement of students $(\rho$-value $=0.891)$ and found a correlation between the activity of intra-campus activities to academic achievement of students ( $\rho$ value $=0.021$ ). There is a relationship between the level of activity of intracampus activities to academic achievement of students.
\end{abstract}

Keywords: Relationship Study Style, Achievements, Activity

\section{Introduction}

Competition in the world of work is getting tougher as the development of knowledge is increasingly developing (Pearce, 2004; Brown \& Williams, 2004; Srnicek \& Williams 201). In a university, it has a very important role in the development of human resources (HR) and in increasing the competitiveness of students. Organizational activeness is one way that can be used to improve and develop student personalities and become a factor in their acceptance in the world of work 1.

A similar opinion is also shown by the results of research conducted by Huang and Chang (2004, p. 391) explaining that students who are active in academic and co-curricular activities have benefits in strengthening thinking skills, communication skills, interpersonal skills, and self-confidence. Students must have the intelligence to turn barriers into success in the form of Adversity Quotient (AQ). Besides that, you must have good Intelligence Quotient (IQ) and Emotional Quotient (EQ), especially as a medical student in order to have a strong fighting power or competitiveness to change the difficulties faced during the education period into a platform for success in achieving your goals as a person.

In the context of the medical profession, this competence implies an integration of the ability to think, act and behave as a doctor. Every professional action of a doctor must be based on the results of thinking that can be scientifically justified, carried out in accordance with established standard procedures, and accompanied by attitudes and behavior in accordance with ethics, code of ethics, and the responsibilities of a doctor.

This phenomenon is very interesting, is it true that there is a difference in academic performance as assessed from the cumulative grade point index between learning styles and students who are active in organizations, (Din, 2009; Junco, 2015; Jajun \& Zinkhan 2002) This is important to know, especially for students who live it, but unfortunately until now there has been no further research on this matter. This makes the author interested in investigating a research with the title "Learning Styles Activity level and Medical Students' Learning Performance". 


\section{Methods}

The approach used is cross sectional. In this type the independent and dependent variables are assessed simultaneously at one time, so there is no follow-up. In this study, the study population was students who met the inclusion and exclusion criteria. The design used in this study is analytical category using cross sectional approach. Data were analyzed using ChiSquare test.

\section{Results and Discussion}

Data collection was carried out from January 3, 2019 to February 1, 2019 for the Students. The number of respondents as the research sample was 49 people using total sampling, and after selecting the sample using inclusion criteria and the exclusion criteria obtained a sample of 43 people. Retrieval of data using a measuring instrument in the form of a questionnaire and student data obtained from the Student Academic field.

The results of the study were obtained using several questionnaires consisting of questionnaires about learning styles and organization and academic achievement. The questionnaire was distributed to each respondent and then filled out directly and assisted by the researcher.

After data collection, the next step is data processing to obtain the results of this study. Data processing using the SPSS 21.00 for windows program. Furthermore, the complete research results will be presented in table form including the distribution of characteristics based on gender, distribution of learning style characteristics, intra-campus activities, and distribution of academic achievement characteristics based on univariate data analysis and bivariate analysis to see the relationship between the independent variable and the dependent variable using the chi-square test where the significance value $\alpha=0.05$

\section{Analysis}

\section{Univariate Analysis}

Table V.1 Distribution of characteristics of students based on gender

\begin{tabular}{lll}
\hline Sex & $\begin{array}{l}\text { Amount } \\
(\mathbf{N})\end{array}$ & $\begin{array}{l}\text { Persentage } \\
(\boldsymbol{\%})\end{array}$ \\
\hline Male & 8 & 18,6 \\
Female & 35 & 81,4 \\
\hline Total & $\mathbf{4 3}$ & $\mathbf{1 0 0}$ \\
\hline
\end{tabular}

(Source: Primary data, February 2019 obtained from questionnaires)

Table 5.1, above shows the characteristics of respondents based on gender. It can be seen that 35 female respondents $(81.4 \%)$ and 8 male respondents $(18.6 \%)$.

Table V.2 Distribution of student characteristics of based on learning styles

\begin{tabular}{|c|c|c|}
\hline $\begin{array}{l}\text { Types } \\
\text { Learning Style }\end{array}$ & $\begin{array}{l}\text { Amount } \\
(\mathbf{N})\end{array}$ & $\begin{array}{l}\text { Persentage } \\
(\%)\end{array}$ \\
\hline Visual & 4 & 9,3 \\
\hline Auditory & 20 & 46,5 \\
\hline Read/Write & 3 & 7,0 \\
\hline Kinesthetic & 16 & 37,2 \\
\hline Total & 43 & 100 \\
\hline
\end{tabular}

1 (Source: Primary data for February 2019 obtained from questionnaires) 
Table 5.2, above shows the characteristics of respondents based on learning styles. It can be seen from 43 people, who have a frequency of visual learning styles on academic activities as many as 4 people $(9.3 \%)$, the frequency of auditory learning styles is 20 people $(46.5 \%)$, the frequency of learning styles read / write 3 people $(7,0 \%)$, and the frequency of kinesthetic learning styles 16 people (37.2\%) on academic activities .

Table V.3 Distribution of characteristics of students of based on the level of activity of intracampus activities (organizations)

\begin{tabular}{lll}
\hline $\begin{array}{l}\text { Intra } \\
\text { Activities } \\
\text { (Organization) }\end{array}$ & $\begin{array}{l}\text { Amount } \\
(\mathbf{N})\end{array}$ & $\begin{array}{l}\text { Persentage } \\
(\boldsymbol{\%})\end{array}$ \\
\hline Active & 37 & 86,0 \\
Passive & 6 & 14,0 \\
\hline Total & $\mathbf{4 3}$ & $\mathbf{1 0 0}$ \\
\hline
\end{tabular}

(Source: Primary data, February 2019 obtained from questionnaires)

Table 5.3, above, shows the characteristics of the respondents based on intra-campus (organizational) activities. It can be seen from 43 people, who have an active frequency of intra-campus (organization) activities as many as 37 people (86.0\%) and a passive frequency of intra-campus (organization) activities as many as 6 people $(14.0 \%)$

Table V.4 Distribution of the characteristics of students based on Academic Achievement (GPA)

\begin{tabular}{lll}
\hline $\begin{array}{l}\text { Academic } \\
\text { achievement } \\
\text { (GPA) }\end{array}$ & $\begin{array}{l}\text { Amount } \\
(\mathbf{N})\end{array}$ & $\begin{array}{l}\text { Persentage } \\
(\boldsymbol{\%})\end{array}$ \\
\hline Very satisfy & 27 & 62,8 \\
Less satisfactory & 16 & 37,2 \\
\hline Total & $\mathbf{4 3}$ & $\mathbf{1 0 0}$ \\
\hline
\end{tabular}

(Source: Secondary Data, February 2019 obtained from the Academic Archives)

Table 5.4, above, shows the characteristics of the respondents based on academic achievement (GPA). It can be seen from 43 people, who have a very satisfying frequency of academic achievement (GPA) as many as 27 people (62\%) and an unsatisfactory frequency of academic achievement (GPA) as many as 16 people (37.2\%).

\section{Bivariate Analysis}

Table V.5 Relationship between Learning Style and Academic Achievement

\begin{tabular}{lllllllll}
\hline \multicolumn{7}{l}{ Academic achievement } \\
Learning style & Very satisfy & \multicolumn{2}{l}{$\begin{array}{l}\text { Less } \\
\text { satisfactory }\end{array}$} & Amount & $\begin{array}{l}\text { Grade } \\
p\end{array}$ \\
& $\mathrm{~N}$ & $\%$ & $\mathrm{~N}$ & $\%$ & $\mathrm{~N}$ & $\%$ & \\
& 2 & 50 & 2 & 50 & 4 & 100 & \\
Visual & 12 & 60 & 8 & 40 & 20 & 100 & 0,894 \\
Auditory & 2 & 66,7 & 1 & 33,3 & 3 & 100 & \\
Read/write & 11 & 68,8 & 5 & 31,3 & 16 & 100 & \\
Kinesthetic & & & & & & &
\end{tabular}




\begin{tabular}{lllllll}
\hline Total & 27 & 62,8 & 16 & 37,2 & 43 & 100 \\
\hline
\end{tabular}

(Source: Primary and Secondary Data, February 2019 obtained from Questionnaires and Academic Archives)

Table 5.5 shows that the respondents who have a visual learning style for academic activities are 4 people $(100 \%)$, there are 2 people $(50 \%)$ who are very satisfying towards academic performance and there are 2 people (50\%) who are not satisfactory towards academic performance. Respondents who have an auditory learning style for academic achievement (GPA) are 20 people (100\%), there are 12 people (60\%) who are very satisfying towards academic performance (GPA) and there are 8 people (40\%) who are not satisfactory towards academic performance ( GPA). Respondents who have a read / write learning style for academic activities as many as 3 people $(100 \%)$, there are 2 people $(66.7 \%)$ who are very satisfying towards academic performance and there is 1 person (33.3\%) who are not satisfactory towards academic presentation ( GPA). Respondents who have a kinesthetic learning style towards academic presentation (GPA) are 16 people (100\%), there are 11 people $(68.8 \%)$ who are very satisfying towards academic performance (GPA) and there are 5 people $(31.3 \%)$ who are unsatisfactory against academic presentation (GPA).

From the results of statistical tests with the Chi-Square test method shows that $\mathrm{p}$ value 0.894 $(\mathrm{p}<0.05)$ means that student academic achievement is not influenced by the learning style they use. Based on the results of data analysis, it can be concluded that the learning style has no effect on the academic achievement (GPA) of students.

Table V.6 The Relationship of Intra-Campus (Organization) Activities Against Academic Achievement of Students

\begin{tabular}{|c|c|c|c|c|c|c|c|}
\hline \multicolumn{8}{|c|}{ Academic achievements (IPK) } \\
\hline $\begin{array}{l}\text { Intra Campus } \\
\text { Activities } \\
\text { (Organizations) }\end{array}$ & \multicolumn{2}{|c|}{ Very Satisfy } & \multicolumn{2}{|c|}{$\begin{array}{l}\text { Less } \\
\text { Satisfactory }\end{array}$} & \multicolumn{2}{|c|}{ Total } & \multirow[t]{2}{*}{$\begin{array}{l}\text { Grade } \\
p\end{array}$} \\
\hline \multirow{3}{*}{$\begin{array}{l}\text { Active } \\
\text { Passive }\end{array}$} & $\mathrm{N}$ & $\%$ & $\mathrm{~N}$ & $\%$ & $\mathrm{~N}$ & $\%$ & \\
\hline & 26 & 70,3 & 11 & 29,7 & 37 & 100 & \multirow{2}{*}{0,021} \\
\hline & 1 & 16,7 & 5 & 83,3 & 6 & 100 & \\
\hline Total & 27 & 62,8 & 16 & 37,2 & 43 & 100 & \\
\hline
\end{tabular}

(Source: Primary and Secondary Data, February 2019 obtained from Questionnaires and Academic Archives)

Table 5.6 shows that there were 37 respondents who were active in intra-campus (organization) activities (100\%), there were 26 people $(70.3 \%)$ who were very satisfied with their academic achievement (GPA) and there were 11 people $(29.7 \%)$ who less satisfactory to academic achievement (GPA). There were $6(100 \%)$ passive respondents to intra-campus (organization) activities as many as 1 person (16.7\%) who lacked academic achievement (GPA). And there are 5 people (83.3\%) who are good at academic achievement (GPA).

From the results of the statistical test with the Chi-Square test method, it shows that the $p$ value is $0.021(\mathrm{p}<0.05)$, which means that there is a significant relationship between the level of activity of intra-campus (organization) activities and the academic achievement (GPA) of students. 
In this research, it has been conducted regarding the relationship between the level of activity of intra-campus activities on academic achievement of students were collected from students based on inclusion and exclusion criteria. Data collection began on January 3, 2019 until February 1, 2019. Based on the general characteristics of the research carried out, the students who had or temporarily participated in academic and intra-campus activities and students who had passed a number of courses (blocks) in lectures.

\section{The Relationship between Learning Style and Academic Presentation}

Based on the results of statistical tests using the Chi-Square test with a significance level of 0.05 , the results of research on learning styles on academic achievement of students showed no significant relationship. This is evidenced by the results of statistical tests showing $\mathrm{p}$ value $=0.894(\mathrm{p}<0.05)$ means that $\mathrm{Ha}$ is rejected and $\mathrm{H}_{0}$ is accepted. This means that statistically there is no significant relationship between the level of learning styles and the academic achievement of students.

Student cumulative performance index is influenced by external and internal factors. External factors include family environment, social environment, curriculum, while internal factors that affect the cumulative grade point of students include intelligence or intelligence, talent, interest and learning motivation (Farrington et al, 2012; Neisser, 1996; Horton, 2015). In addition, the student's approach to the assignment determines the extent to which students are involved with the subject and affects learning outcomes. A deep approach to learning is characterized by a desire to understand and seek meaning, which encourages students to try to connect concepts with existing understandings and with one another, distinguish between new ideas and existing knowledge, and critically evaluate and define key themes and concepts. The surface approach to learning is characterized by a desire to complete tasks, memorize information, make no distinction between new ideas and existing knowledge, and treat tasks as imposed from without.

However, this research is not in line with the research conducted by Hawk \& Shah (2011) which stated that the learning style most students use is the visual learning style. with 6 students with a GPA of 2.00-2.75 and 19 students with a GPA of 2.751-3.50. So it shows that learning styles provide a meaningful relationship to learning achievement and is one of the factors that greatly influence learning achievement. The factors that affect learning achievement are classified into two groups, namely:

An overview of learning styles on academic achievement in students with 43 respondents. The learning styles that most students have with a very satisfying cumulative grade point average are auditory learning styles followed by kinesthetic learning styles and with the same number of visual and read/write learning styles. Furthermore, students who have a less satisfactory achievement index are auditory learning styles followed by kinesthetic learning styles and finally, visual learning styles and read / write learning styles.

\section{The Relationship between Intra-campus Activity Levels and Academic Presets}

Hip between the level of activity of intra-campus activities on the academic achievement of students. The results of this study showed a very significant relationship. This is also in line with previous research (Adeyemo, 2010; Kamp et al, 2012; Cooper et al, 2012; Camp, 1990) concerning the Relationship between Students Joining Intra-School Organizations and Learning achievement.

\section{Conclusion}

From the results of research that has been carried out with the title "Relationship learning styles and the level of student activeness in participating in intra-campus activities towards 
the 2016 Class Student Grade Point Average: Learning styles for students with a total of 43 people, 4 people $(9.3 \%)$ have visual learning styles for academic activities, 20 auditory learning styles (46.5\%), frequency learning styles read/write 3 people, and the frequency of kinesthetic learning styles 16 people on academic activities. Intra-campus (organization) activities for students with a total of 43 people having an active frequency of intra-campus (organization) activities of 37 people and a passive frequency of intra-campus (organization) activities of 6 people. Academic Achievement in students with a total of 43 people having a very satisfying frequency of academic achievement (GPA) of 27 people and an unsatisfactory frequency of academic achievement (GPA) of 16 people. Research on the Relationship of Learning Styles to Academic Achievement, the results show that learning styles have no significant effect on academic achievement. Research on the Relationship of Intra-Campus Activity Levels of the Academic Achievement showed that the level of intra-campus activity had a significant effect on academic achievement.

\section{References}

Adeyemo, S. A. (2010). The relationship between students participation in school based extracurricular activities and their achievement in physics. International Journal of Science and Technology Education Research, 1(6), 111-117.

Brown, P., Hesketh, A., \& Williams, S. (2004). The mismanagement of talent: Employability and jobs in the knowledge economy. Oxford University Press on Demand.

Camp, W. G. (1990). Participation in student activities and achievement: A covariance structural analysis. The Journal of Educational Research, 83(5), 272-278.

Cooper, H., Valentine, J. C., Nye, B., \& Lindsay, J. J. (1999). Relationships between five after-school activities and academic achievement. Journal of educational psychology, 91(2), 369.

Din, M. (2009). A Study In Indices Of Discrepancy Between Students'learning Styles And Their Actual Grade Achievement At Masters'level (Doctoral Dissertation, National University Of Modern Languages (Numl) Islamabad).

Farrington, C. A., Roderick, M., Allensworth, E., Nagaoka, J., Keyes, T. S., Johnson, D. W., \& Beechum, N. O. (2012). Teaching Adolescents to Become Learners: The Role of Noncognitive Factors in Shaping School Performance--A Critical Literature Review. Consortium on Chicago School Research. 1313 East 60th Street, Chicago, IL 60637.

Hawk, T. F., \& Shah, A. J. (2007). Using learning style instruments to enhance student learning. Decision Sciences Journal of Innovative Education, 5(1), 1-19.

Horton, J. (2015). Identifying at-risk factors that affect college student success. International Journal of Process Education, 7(1), 83-101.

Huang, Y. \& Chang, S. (2004). Academic and cocurricular involvement: Their relationship and best combinations for student growth. Journal of College Student Development, 45 (4), 391-406.

Jaju, A., Kwak, H., \& Zinkhan, G. M. (2002). Learning styles of undergraduate business students: A cross-cultural comparison between the US, India, and Korea. Marketing Education Review, 12(2), 49-60.

Junco, R. (2015). Student class standing, Facebook use, and academic performance. Journal of Applied Developmental Psychology, 36, 18-29. 
Kamp, R. J., Dolmans, D. H., van Berkel, H. J., \& Schmidt, H. G. (2012). The relationship between students' small group activities, time spent on self-study, and achievement. Higher Education, 64(3), 385-397.

Neisser, U., Boodoo, G., Bouchard Jr, T. J., Boykin, A. W., Brody, N., Ceci, S. J., ... \& Urbina, S. (1996). Intelligence: knowns and unknowns. American psychologist, 51(2), 77.

Pearce, C. L. (2004). The future of leadership: Combining vertical and shared leadership to transform knowledge work. Academy of Management Perspectives, 18(1), 47-57.

Srnicek, N., \& Williams, A. (2015). Inventing the future: Postcapitalism and a world without work. Verso Books. 